SCADidoc

Infer, Interpret \& Inspire Science
International Journal of Anatomy and Applied Physiology (IJAAP)

ISSN: 2572-7451

\title{
Neurochemical Observations after the Transplantation of Human Amniotic Epithelial Cells in 2, 4, 5-trihydroxyphenylethylamine (6-OHDA) induced Parkinsonism Disease Model in Wistar albino rats
}

Research Article

Ravisankar Periyasamy ${ }^{*}$, Ramesh Kumar ${ }^{2}$, Ravindran Rajan ${ }^{3}$, Omprakash Kasaragod ${ }^{4}$

${ }^{1}$ Department of Anatomy, SRM.Dental College \& Hospital, SRM Institute of Science and Technology, Ramapuram Campus, Bharathi Salai, Chennai. ${ }^{2}$ Department of Anatomy, Dr. A. L. Mudaliar Post Graduate Institute of Basic Medical Sciences, University of Madras, Taramani Campus, Taramani, Chennai.

${ }^{3}$ Department of Physiology, Dr. A. L. Mudaliar Post Graduate Institute of Basic Medical Sciences, University of Madras, Taramani Campus, Taramani, Chennai.

${ }^{4}$ Department of Anatomy, Hassan Institute of Medical Sciences, Hassan-573201, Karnataka, India.

\section{Abstract}

Background: In the present work the dopamine (DA) denervated rats exhibited vigorous contralateral rotational behaviour following apomorphine hydrochloride (APO Hcl) treatment. The 2, 4, 5-trihydroxyphenylethylamine (6-OHDA) lesioned animals showed significantly increased contralateral rotation. From the first week onwards the researcher observed changes in the lesion-induced rotational behaviour with the dopaminergic agnostic drug APO Hcl for fifty-sixty minutes from the time of administration. The lesioned animals showed more than 25.40 folds of rotations were taken for the Human Amniotic Epithelial (HAE) cells transplantation.

Objective: To study the role of HAE cells in rotational behaviour and the level of dopamine and its metabolites indiscrete regions of the brain in 6-OHDA lesionedwistar albino rats.

Material and Methods: Total of 48 Adult male Wistar albino rats weighing 180-220 gms were used for this study and were divided into four groups. They were maintained in a room at constant temperature and humidity $\left(21^{\circ} \mathrm{C}\right.$ to $\left.26^{\circ} \mathrm{C}\right)$ and $12 \mathrm{~h}$ light and dark cycle during the behavioural test and surgery. The DA and its metabolites were studied usinghigh-performance liquid chromatography with electrochemical detection (HPLC- ECD) method.

Results: The HAE cells transplanted animals showed decreased contralateral rotation for first week $96 \%$, second week $97 \%$, third week $98 \%$ and fourth week $97 \%$ over the 6-OHDA lesioned animals. The level of DA and its metabolites in these animals were significantly increased in transplanted side than the contralateral side of 6-OHDA lesioned animals. The maximum significant increase was observed in striatum (DA 44.5 fold, 3,4-Dihydroxyphenylacetic acid (DOPAC) 44.9 fold and homovanillic acid (HVA) 1.9 folds) and minimum increase was in cerebral cortex (DA $30 \%$, DOPAC 2 fold and HVA 2 fold) among the brain regions studied after the HAE cells graft from the 6-OHDA lesion.

Conclusion: Increase of DA and its metabolites in brain region after the HAE cells graft may therefore probably be dependent upon the diffusion of certain neurotrophic factors in the region of graft in the striatum and also due to intimacy of contact between the graft and the host striatum.

Keywords: 6-OHDA Lesion; Apomorphine Induced Rotations; Human Amniotic Epithelial (HAE) Cells; Dopamine (DA); 3,4-dihydroxyphenylacetic Acid ( DOPAC); Homovanillic Acid (HVA).

\section{Introduction}

Parkinson's disease (PD) is one of the most common neurodegenerative movement disorders. The most marked pathological change in this disease is selective degeneration of the nigrostriatal dopaminergic neurons in the central nervous system [1]. The anatomical and functional changes in PD may be classified into a three phase model explained by Peran et al., (2010) [2]. There are at least two possible explanations for the elevated DA turnover in residual neurons after partial lesions of dopaminergic projection. First one is the increase of DA which is mediated by a change in the firing of the remaining dopaminergic neurons. Indeed chang-

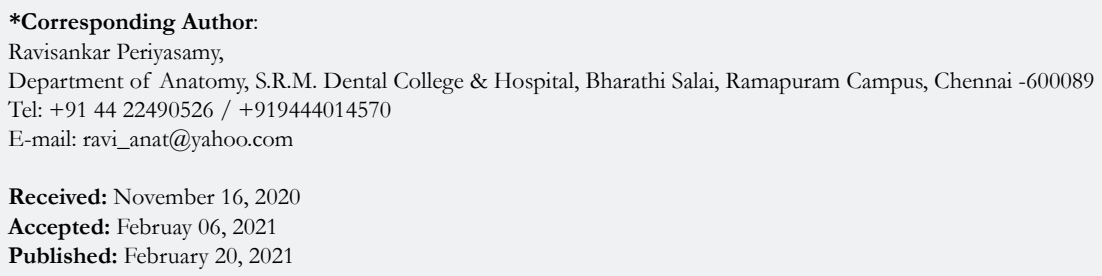

Copyright: Ravisankar Periyasamy ${ }^{\odot}$ 2021. This is an open-access article distributed under the terms of the Creative Commons Attribution License, which permits unrestricted use, distribution and reproduction in any medium, provided the original author and source are credited. 
es in both the rate and the pattern of firing in those dopaminergic neurons have been observed and may serve to promote an increase in DA release [3]. Second the dopaminergic cells shows an increase in burst firing and this firing is thought to be associated with the elevation of DA release per impulse [4].

Dopamine transporters (DATs) are expressed in dopaminergic neurons and their expression may be a significant marker of dopaminergic nerve cells. It is known that DATs in nigrostriatal system may take part in the pathogenic mechanism of PD. Dopamine transporters messenger RNAsare decreased markedly in the brain of animal model induced by 1-methyl-4-phenyl-1,2,3,6tetrahydropyridine (MPTP) and PD patients [5, 6]. The administration of 6-OHDA into the brain of the rat produces a wellestablished model of PD [7-10].

The HAE cells are derived from embryonic epiblast cells prior to the gastrulation and possess some features of their founder pluripotent stem cells including the ability to differentiate into multiple lineages derived from the primary germ layers [11]. Unlike adult bone marrow derived stem cells, the HAE cells are highly abundant and easily harvested from term delivered amnion membranes typically yielding over $150 \times 106$ cells / membrane and thereby minimizing the need for expensive and time consuming cell expansion[12]. Importantly, like other fetal derived placental cells that evade maternal immune recognition and secrete factors are known to dampen maternal immune responses against the fetal semi-allograft. The HAE cells have also been shown to have low immunogenicity and the capacity to modulate innate and adaptive immune cell responses [12-14]. Recent work have reported that the HAE cells transplantation increased brain derived neurotrophic factor (BDNF) and tropomysin related kinase B (Trk B) expression and related to the enhanced hippocampal neurogenesis in Autism Spectrum Disorder (ASD) in BTBR mice[15]. As such, the goals of this study is to determine the effects of DA denervation and survival of transplanted HAE cells on rodent, measures monoamine levels via high-performance liquid chromatography with the electrochemical detection (HPLC-ECD) of tissue which is taken from different areas of the brain.

\section{Material and Methods}

\section{Animals}

Adult male wistar albinorats weighing 180-220gms were used for this study. They were maintained in a room at constant temperature and humidity $\left(21^{\circ} \mathrm{C}\right.$ to $\left.26^{\circ} \mathrm{C}\right)$ and $12 \mathrm{~h}$ light and dark cycle. Animals were allowed ad libitum access to food and water except during the behavioural tests and surgery. The experiments were conducted in accordance with the standard guidelines of the Institutional Animal Ethical Committee (Approval No 01/008/03).

\section{Experimental Groups}

The rats were randomly divided into four groups. Group-I: Control- Not exposed to any surgical interventions. Group-II: Sham- $10 \mu \mathrm{l}$ ascorbate saline $(0.2 \%$ ascorbic acid in saline) injected in to the striatum stereotaxically. Group-III:Lesioned - $20 \mu \mathrm{g}$ of 6-OHDA (H4381-Sigma)in 10 $\mu$ l of ascorbate saline injected into the striatum stereotaxically. Group-IV: Lesion cum transplant Sterotaxically injected into the striatum with 6-OHDA $20 \mu \mathrm{g}$ in
$10 \mu \mathrm{l}$ of ascorbate saline, followed by the Human Amniotic Epithelial (HAE) cells transplant.

\section{Stereotaxic enabled 6 OHDA injection in rat striatum}

The rats were anaesthetized by intra-peritoneal administration of PentothalSodium at the dose of $40 \mathrm{mg} / \mathrm{kg}$ of body weight. Anesthetized rats were fixed to the stereotaxic apparatus,incisors bars were set at-3.3 and 1.0. The rats were immobilized in a stereotaxic frame in the flat skull position and mid-sagital skin incision was made on the scalp for $2 \mathrm{~cm}$ length to expose the skull.With reference to the Paxinos and Watson (1985) [16] rat stereotaxic atlasthe following stereotaxic coordinates were used to place the cannula $\mathrm{AP}=0.2 \mathrm{~mm}, \mathrm{ML}=3.2 \mathrm{~mm}, \mathrm{DV}=4.5 \mathrm{~mm}$ from the Bregma. With these co-ordinates the dorso-lateral part of the striatum was targeted. Another target was the dorso-medial part of striatum reached by the co-ordinates, $\mathrm{AP}=1.1 \mathrm{~mm}, \mathrm{ML}=2.4 \mathrm{~mm}$ and $\mathrm{DV}=3.5 \mathrm{~mm}$. Freshly prepared 6-OHDA $(20 \mu \mathrm{g}$ in $10 \mu \mathrm{l}$ of ascorbate saline) was injected unilaterally (right side) at each targeted site.This was prepared on the same day and protected from the light till the time of infusion. The 6-OHDA injection was done slowly at the rate 0.5 to $1 \mu \mathrm{l}$ per minute through 26gauge stainless steel cannula connected to a $10 \mu$ l Hamilton micro syringe $(\mathrm{P} / \mathrm{N}$ : 80300/00 Hamilton Bonaduz AG, CH-7402, Switerzerland). After the infusion, the canula was retained for five minutes and then the rats were transferred to post-operative care unit and proper care was given to the rats for seven days.

\section{Drug and dosage}

The specificity of 6-OHDA neurotoxicity has been associated with its uptake and accumulation by transport mechanism specific for catecholaminergic neurons. One $\mathrm{mg}$ of 6-OHDA was dissolved in $0.5 \mathrm{ml}$ of Ascorbate saline. $(0 \bullet 02 \mathrm{~g}$ of ascorbic acid was dissolved in $10 \mathrm{ml}$ of sterile normal saline, to prepare ascorbate saline). Thirty minutes before the 6-OHDA injection the Desipramine hydrochloride (D3900-Sigma) (25mg/kgbody weight/i.p) was injected. When critical intranueral concentration of 6-OHDA or its metabolites is attained, then destructive processes begin and cellular enzymes and energy-producing cytochromes or related elements of the respiratory transport chain will be destroyed (Fig.1) $[17]$.

\section{Isolation of amniotic epithelial cells from the human pla-} centa

The human placenta was obtained from an uncomplicated elective caesarean section after obtaining the consent of the patient admitted at Andhra MahilaSaba Hospital, Adayar, Chennai-600020. Isolation of the HAE(Human amniotic epithelium)cellsfollowed the method of Sakurgawa et al. [18, 19]. Briefly after separation from the placenta the connective tissue was completely removed by scraping with cotton, membrane was then treated with $0.125 \%$ trypsin (Hi-media) three times each for $20 \mathrm{~min}$. The HAE cells obtained after second and third treatment were cultured in Minimum Essential Medium (MEM) (AT 006) or RPMI 1640 (AT 028) (Hi media) medium supplemented with $10 \%$ fetal calf serum under a humidified atmosphere of $5 \% \mathrm{CO} 2$ in air at $37^{\circ} \mathrm{C}$. The cells were counted using a haemo-cytometer with the tryphan blue exclusion method before transplanting into the lesioned striatum.

Labeling of human amniotic epithelial cell with DiI: Five 
Figure 1. Mechanism and action of the 6-OHDA (2, 4, 5-trihydroxyphenylethylamine).

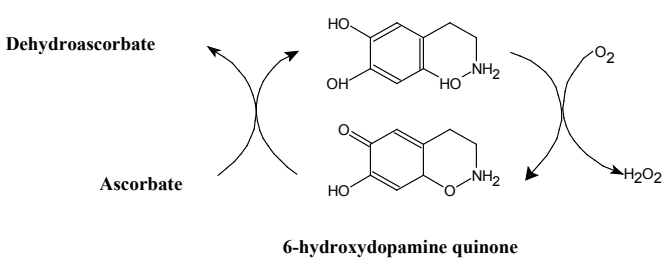

to seven days after the culture, the cultured HAE cells suspension was mechanically dissociated into single cell suspension using phosphate buffered saline (PBS). Before grafting, an aliquot of the cell suspension was assessed for viability through tryphan blue exclusion method. The viability of the cells was $85 \%$ just before the tranplantation. The cultured HAE cells were labeled with fluorescent marker, 1-1'-diotadecyl-3,3,3',3'- tetramethylindoocarbocyanine perchlorate (DiI) and the cultured cell suspension was incubated for $30 \mathrm{~min}$ just prior to the transplantation into the lesioned striatum.

Human amniotic epithelial cells transplantation: 5 to $10 \mu \mathrm{l}$ of cell suspension $(2 \times 104$ cells $/ \mu \mathrm{l})$ were sterotaxically injected into the denervated striatum of rats using a $10 \mu$ l hamilton micro syringe fitted with a steel cannula. The cultured HAE cells were transplanted using following co-ordinates: $1 . \mathrm{AP}=0.2, \mathrm{ML}=2.7$, $\mathrm{DV}=5.5$ and 2. $\mathrm{AP}=1.1, \mathrm{ML}=2.7, \mathrm{DV}=5.5$. The injection was made at the rate of $1 \mu \mathrm{l} / \mathrm{min}$. After the completion of the injection; the cannula was left insitu for another five minutes in order to prevent the backflow of injected HAE cells suspension. Immediately after the HAE cells transplantation, the cyclophosphamide (239785-Sigma) was given at the dose of $5 \mathrm{mg} / \mathrm{kg}$ body weight for 3 days to prevent the graft versus host rejection.

\section{Apomorphine induced rotation}

The apomorphine-induced rotation was carried out 10 to 12 days after the 6-OHDA lesions. $0.05 \mathrm{mg} / \mathrm{kg} /$ bwof Apomorphinehydrochloride (A4393-Sigma) was injected through subcutaneous route in the neck region. We followed the basic principles of rotational behaviour study described by Ungerstedt; Olsson et al. [20], [21]. With the modification, we simplified the observation on rotational behaviour. Each animal was placed in a glass cylinder measuring $30 \mathrm{~cm}$ height and $22 \mathrm{~cm}$ diameter and the number of rotation of the animals in cylinder were counted over a period of $60 \mathrm{~min}$.

\section{Dissection of discrete brain regions}

All the sample collections were done between 8-9AM in order to avoid circadian rhythm induced variation. The rats were sacrificed by cervical dislocation using the method of Glowinski [22]. After the sacrifice, the brain was rapidly removed. To expose the brain, the tip of curved scissors was inserted into the foramen magnum and a single lateral cut was made into the skull extending forward on the left and right side. With a bone cutter the dorsal portion of cranium was peeled off and by means of blunt forceps, thebrainand dropped onto the ice cold glass plate leaving the olfactory bulbs behind. The whole process of removing brain took less than 2 minutes. After removing the brain, it was blotted and chilled. Further dissection was made on ice-cold glass plate to collect the striatum, the midbrain, the cerebral cortex and the hippocampus.

\section{Brain Neurotransmitters}

The various brain biogenic amines in the discrete regions of the rat brain were estimated by the method of Glowinski [22]. Concentrations of Dopamine (DA), 3,4-dihydroxyphenylacetic acid (DOPAC) and Homovanillic acid (HVA) were measured in high performance liquid chromatography (HPLC) and C18 column (WATERS high resolution, Non end-capped) coupled with electrochemical detection (Decade II, HPLC Electrochemical (EC) detector (ANTEC Scientific).

Specimen preparation: The discrete brain regions were homogenized using motor driven Teflon-glass tissue homogenizer with $60 \mathrm{mg} / \mathrm{ml}$ of ice-cold $0.1 \mathrm{M}$ perchloric acid. Homogenates were centrifuged at $6,000 \mathrm{~g}$ in a refrigerated centrifuge for $2 \mathrm{~min}$. internal standard was added with the supernatant and again centrifuged at $35,000 \mathrm{~g}$ for $20 \mathrm{~min}$. Supernatant was filtered with $0.22 \mu$ membrane filter. $20 \mu \mathrm{l}$ of sample contained $200 \mathrm{pg}$ of internal standard.

Mobile phase for dopamine and its metabolites: The mobile phase is consisted of $50 \mathrm{mM}$ sodium acetate, $50 \mathrm{mM}$ citric acid, $0.4 \mathrm{mM}$ sodium octylsulfate, $1.1 \mathrm{mM}$ n-dibutyl amine, $0.15 \mathrm{mM}$ EDTA-Na2 and $5 \%(\mathrm{v} / \mathrm{v})$ methanol/water.

For catecholamine assay, discrete brain regions were rapidly removed, weighed and homogenized in ice-cold $0.2 \mathrm{M}$ perchloric acid containing $1 \mathrm{mM}$ EDTA-Na4 and $0.4 \mathrm{mM}$ S2O5Na to prevent DA auto oxidation. The homogenates were centrifuged at 15,000 $\times \mathrm{g}$ for $20 \mathrm{~min}$ at $4^{\circ} \mathrm{C}$ and the supernatant were passed through a $0.22 \mu \mathrm{m}$ filter and analyzed by HPLC-ECD[23]. Separations were done in a C-18 reversed-phase $5 \mu \mathrm{m}$ sphere analytical column. The potential applied was set at $+0.65 \mathrm{~V}$ using a glassy carbon electrode versus an $\mathrm{Ag} / \mathrm{AgCl}$ reference electrode. The solution was filtered through a $0.45 \mu \mathrm{m}$ filter and degassed before use. Analysis was done at a flow rate of $0.8 \mathrm{ml} / \mathrm{min}$ at room temperature. The concentrations of DA, DOPAC and HVA in the samples were calculated using 3, 4, dihydroxy benzyl amine hydrobromide (DHBA) (858781-Sigma) as an internal standards and a calibration curve was obtained from the corresponding standards injected in the HPLC system. The retention times were 4.9 min for DHBA, $6 \mathrm{~min}$ for DOPAC, $7.7 \mathrm{~min}$ for DA and 14.8min for HVA (Fig.2). Monoamines and their metabolites in the samples could be easily identified comparing their retention times and electrochemical characteristics with those of their corresponding standards, and their concentrations were expressed in $\mathrm{ng} / \mathrm{g}$ wet tissue.

\section{Statistical analysis}

The data were evaluated using One-way ANOVA (SPSS, Version 14.0 USA) and the values were expressed as Mean \pm S.E, the level of significance was determined by "Tukey'sposthoc" test and P 
values $<0.05$ was considered statistically significant.

\section{Results}

\section{Apomorphine induced rotation}

In this study the sham lesioned animals (Group II) did not show any abnormal rotations after the APO Hclinjection in all the duration of rotational behavioural test. The group III animals showed significant increase in contralateral rotation (First week 26.60 folds; Second week 27.04 folds; Third week 25.75 folds and Fourth week 25.72 folds) when compared to the non lesioned control animals (Group I) in all the period. Whereas group IV animals exhibited decrease in contralateral rotation by $96 \%$ in the first week, 97\% in the second week, 98\% in third week and 97\% in fourth week when compared to the group III animals (Table-1; Graph I). In contrast to group III, reduced asymmetric rotation in the group IV animal would depend on placement and interaction of the HAE cells graft within the denervated striatum.

\section{Neurotransmitters}

Normally the quantities of DA and its metabolites DOPAC and HVA would be greater in the striatum and the midbrain than the other regions of the brain. The percentage of DA, DOPAC and HVA was calculated by dividing the amount of each compound in the lesioned animals with the control animals. In this study the levels of DA and its metabolites were expressed as ng / g of wet tissue.

Striatum: The level of DA 98\% (Mean 124.33 $\pm 5.91 \mathrm{ng} / \mathrm{g}$ of wet tissue), DOPAC $98 \%$ (Mean $54.00 \pm 1.69 \mathrm{ng} / \mathrm{g}$ of wet tissue), and HVA $73 \%$ (Mean $128.83 \pm 2.54 \mathrm{ng} / \mathrm{g}$ of wet tissue), in right striatum of group III animals were observed to be decreased, when compared to control animal's right striatum $(\mathrm{DA}=$ Mean 5923.16 $\pm 16.49 \mathrm{ng} / \mathrm{g}$ of wet tissue, DOPAC $=$ Mean $2413.00 \pm 31.90$ $\mathrm{ng} / \mathrm{g}$ of wet tissue and HVA $=$ Mean $474.50 \pm 18.43 \mathrm{ng} / \mathrm{g}$ of wet tissue). Non-lesioned contralateral striatum did not show significant reduction in the DA (4\%), DOPAC $(2 \%)$ and HVA $(5 \%)$ levels compared to control animals. However in the right striatum of HAE cells transplanted animals, the levels of DA 44.5 fold (Mean $6551.83 \pm 56.70 \mathrm{ng} / \mathrm{g}$ of wet tissue), DOPAC 44.9 fold (Mean $2422.50 \pm 58.78 \mathrm{ng} / \mathrm{g}$ of wet tissue), and HVA 1.9 fold (Mean $502.50 \pm 27.19 \mathrm{ng} / \mathrm{g}$ of wet tissue) were elevatedsignificantly compared to group III animals, whereas the contralateral striatum of these animals theDA (9\%), DOPAC (2\%), HVA (5\%) levels were increasedand did not display significance when compared to the lesioned animals (Table-2: Graph 2 and 3).

Midbrain: The substantianigra (SN) is the major source for the dopamine found in the striatum and other parts of the brain. The substantianigra pars compacta ( $\mathrm{SN}$ pc) or A9 secretes its secretion through nigro-striatal dopaminergic pathway in the striatum. In 6-OHDA lesioned animals the levels of DA 67\% (Mean $178.33 \pm$

Table 1. Rotation for 60 minutes after Apomorphine induced in 6-OHDA lesion and HAE cells transplantation from first week to fourth week.

\begin{tabular}{|c|c|c|c|c|}
\hline Group & 1st week & 2nd week & 3rd week & 4th week \\
\hline Group I & $9.00 \pm 1.29$ & $10.50 \pm 0.42$ & $11.50 \pm 0.95$ & $11.33 \pm 1.22$ \\
\hline Group II & $9.00 \pm 0.81$ & $7.50 \pm 0.95$ & $6.83 \pm 0.40$ & $6.66 \pm 0.66$ \\
\hline \multirow{3}{*}{ Group III } & $255.66 \pm$ & $305.00 \pm 19.76$ & $319.33 \pm$ & $314.16 \pm$ \\
& 18.17 & $a^{* * *}$ & $26.77 \mathrm{a}^{* * *}$ & 20.92 \\
\cline { 2 - 3 } & $\mathrm{a}^{* * *}$ & & & $\mathrm{a}^{* * *}$ \\
\hline \multirow{3}{*}{ Group IV } & $9.50 \pm 1.11$ & $9.16 \pm 0.79$ & $8.33 \pm 0.21$ & $9.33 \pm 0.49$ \\
\cline { 2 - 5 } & $\mathrm{a}$ NS $\mathrm{b}^{* * *}$ & $\mathrm{a} \mathrm{NS} \mathrm{b}^{* * * *}$ & $\mathrm{a}$ NS $\mathrm{b}^{* * *}$ & \\
\cline { 2 - 5 } & & & & $\mathrm{a}$ NS b*** \\
\hline
\end{tabular}

Values were measured in number of rotation for 60 minutes after $0.05 \mathrm{mg} / \mathrm{kg} / \mathrm{sc}$ apomorphine ; Each value represents mean \pm standard error of six rats; Group I: Control; Group II: Sham control; Group III: 6-OHDA lesioned; Group IV: HAE cells transplant. a- comparison between Group I Vs III \& IV; b- comparison between Group III Vs IV; NS- not significant; $\mathrm{P} \leq 0.001 * * *$; $\mathrm{P} \leq 0.01 * *$; $\mathrm{P} \leq 0.05^{*}$

Graph 1. Rotations for 60 minutes after apomorphine induced in 6-OHDA lesion and HAE cells transplantation from first week to fourth week.

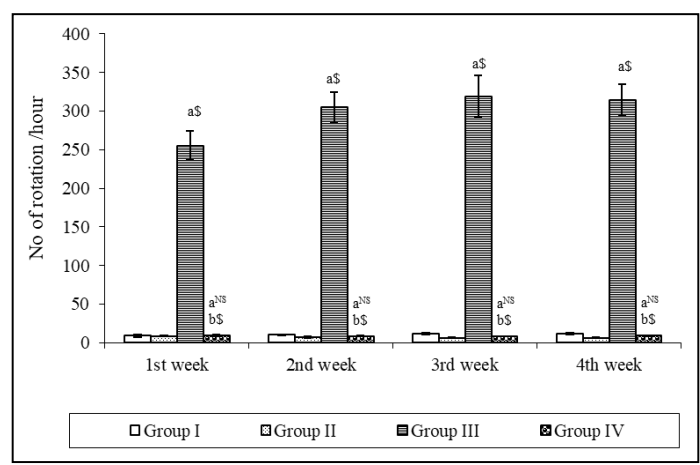

Graph 1.Values were measured in number of rotation for 60 minutes after $0.05 \mathrm{mg} / \mathrm{kg} / \mathrm{sc}$ apomorphine; Each value represents mean \pm standard error of six rats; Group I: Control; Group II: Sham control; Group II: 6-OHDA lesioned; Group IV: HAE cells transplant. a- comparison between Group I vs. III \& IV; b- comparison between Group III vs. IV; NS- not significant; $\mathrm{P} \leq 0.001$-\$; $\mathrm{P} \leq 0.01-\# ; \mathrm{P} \leq 0.05-@$. 
Figure 2. Chromatograph showing DA and its metabolites level in striatum of a sample.

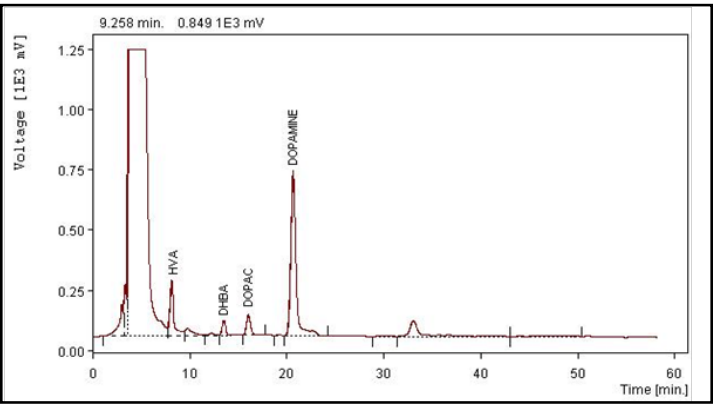

$8.12 \mathrm{ng} / \mathrm{g}$ of wet tissue), DOPAC $72 \%$ (Mean $88.66 \pm 6.07 \mathrm{ng} / \mathrm{g}$ of wet tissue), and HVA 79\% (Mean $105.00 \pm 6.07 \mathrm{ng} / \mathrm{g}$ of wet tissue), in right side midbrain were reduced when compared to the control animals $(\mathrm{DA}=$ Mean $535.16 \pm 18.82 \mathrm{ng} / \mathrm{g}$ of wet tissue, DOPAC $=$ Mean $319.83 \pm 15.14 \mathrm{ng} / \mathrm{g}$ of wet tissue, and $\mathrm{HVA}=$ Mean $494.16 \pm 15.76 \mathrm{ng} / \mathrm{g}$ of wet tissue. In left side midbrain of the same group, the levels of DA $(11 \%)$, DOPAC $(8 \%)$ and HVA $(15 \%)$ were slightly altered or no changes with control animals. In HAE cells grafted animals the right side of midbrain showed significant increases in DA and its metabolites [DA (0.6 fold) Mean $462.00 \pm 25.95 \mathrm{ng} / \mathrm{g}$ of wet tissue, DOPAC (1.5 folds) Mean $311.16 \pm 21.91 \mathrm{ng} / \mathrm{g}$ of wet tissue and HVA (1.8 folds) Mean $395.50 \pm 23.09 \mathrm{ng} / \mathrm{g}$ of wet tissue] contrast to the 6-OHDA lesioned animals. In the left side of HAE cells grafted group there was no much increase in the DA (14\%) and HVA (10\%) levels and no changes in DOPAC (0\%)levels when compared to same side of the lesioned animals (Table-3: Graph 4 and 5).

Cerebral cortex: The levels of DA and its metabolites of right side cerebral cortex of 6-OHDA lesioned animals were significantly reduced, DA $97 \%$ (Mean $77.83 \pm 2.68 \mathrm{ng} / \mathrm{g}$ of wet tissue), DOPAC $79 \%$ (Mean $123.66 \pm 5.27 \mathrm{ng} / \mathrm{g}$ of wet tissue), and HVA $59 \%$ (Mean $220.16 \pm 8.47 \mathrm{ng} / \mathrm{g}$ of wet tissue). Conversely the left side cerebral cortex the DA and its metabolites levels also were altered (DA 34\%, DOPAC 54\% and HVA $34 \%$ ) comparison with control. In group IV animals in the right side cerebral cortex there was significant raise in DA 30\% (Mean $2392.50 \pm 34.14 \mathrm{ng} / \mathrm{g}$ of wet tissue, DOPAC 306\% (Mean 502.66 $\pm 8.69 \mathrm{ng} / \mathrm{g}$ of wet tissue) and HVA 124\% (Mean $494.16 \pm 11.85 \mathrm{ng} / \mathrm{g}$ of wet tissue) concentrations while compared to the 6-OHDA lesioned animals. In left cerebral cortex also they increased moderately (DA 37\%, DOPAC $77 \%$ and HVA 36\%) when compared to the same side of the 6-OHDA lesioned animals (Table-4: Graph 6 and 7).

Hippocampus: The hippocampal afferents are closely related to the dopaminergic neurons in the nucleus accumbens. The concentration of DA $27 \%$ (Mean $858.66 \pm 15.51 \mathrm{ng} / \mathrm{g}$ of wet tissue, DOPAC $79 \%$ (Mean $64.66 \pm 52.21 \mathrm{ng} / \mathrm{g}$ of wet tissue), and HVA $50 \%$ (Mean $4531.83 \pm 38.81 \mathrm{ng} / \mathrm{g}$ of wet tissue)were significantly reducedin right hippocampus of group III, when compared to the group I (control) animals (DA = Mean $1173.50 \pm 28.39 \mathrm{ng} / \mathrm{g}$ of wet tissue, DOPAC $=$ Mean $301.66 \pm 11.34 \mathrm{ng} / \mathrm{g}$ of wet tissue and HVA $=$ Mean $8936.16 \pm 114.08 \mathrm{ng} / \mathrm{g}$ of wet tissue). In the contralateral hippocampus there were no changes in DA metabolites (DOPAC 8\% and HVA (5\%), while the DA levels slightly decreased $(4 \%$ with the non-lesioned control animals. However in the HAE cells transplanted animals the DA and its metabolites were significantly increased in right hippocampus region [DA $(36 \%)$ Mean $1168.16 \pm 26.06 \mathrm{ng} / \mathrm{g}$ of wet tissue, DOPAC $(342 \%)$ Mean $285.50 \pm 9.76 \mathrm{ng} / \mathrm{g}$ of wet tissue and HVA (50\%) Mean $8699.16 \pm 78.00 \mathrm{ng} / \mathrm{g}$ of wet tissue respectively] compared to the 6-OHDA lesioned animals. Although the contralateral hippocam-

Table 2. Level of dopamine and its metabolites in Striatum after 6-OHDA lesion and HAE cells transplantation.

\begin{tabular}{|c|c|c|c|c|c|}
\hline \multicolumn{2}{|c|}{$\begin{array}{c}\text { Parameters } \\
\text { Side(s) }\end{array}$} & Group I & Group II & Group III & Group IV \\
\hline \multirow{4}{*}{$\mathrm{DA}$} & \multirow{2}{*}{ Left } & \multirow{2}{*}{$6240.33 \pm 51.83$} & \multirow{2}{*}{$6198.16 \pm 30.10$} & $6016.00 \pm 28.05$ & $5451.66 \pm 20.08$ \\
\hline & & & & $a^{* * *}$ & $\mathrm{a}^{* * *} \mathrm{~b}^{* * *}$ \\
\hline & \multirow{2}{*}{ Right } & \multirow{2}{*}{$5923.16 \pm 16.49$} & \multirow{2}{*}{$5816.83 \pm 43.16$} & $124.33 \pm 5.91$ & $6551.83 \pm 56.70$ \\
\hline & & & & $a^{* * *}$ & $\mathrm{a}^{* * *} \mathrm{~b}^{* * *}$ \\
\hline \multirow{4}{*}{ DOPAC } & \multirow{2}{*}{ Left } & \multirow{2}{*}{$2474.00 \pm 28.68$} & \multirow{2}{*}{$2410.00 \pm 60.80$} & $2421.50 \pm 31.09$ & $2460.66 \pm 18.44$ \\
\hline & & & & a NS & a NS b NS \\
\hline & \multirow{2}{*}{ Right } & \multirow{2}{*}{$2413.00 \pm 31.90$} & \multirow{2}{*}{$2428.83 \pm 31.99$} & $54.00 \pm 1.69$ & $2422.50 \pm 58.78$ \\
\hline & & & & $a^{* * *}$ & a NS b*** \\
\hline \multirow{4}{*}{ HVA } & \multirow{2}{*}{ Left } & \multirow{2}{*}{$403.00 \pm 26.33$} & \multirow{2}{*}{$409.50 \pm 8.33$} & $381.50 \pm 27.18$ & $399.29 \pm 22.78$ \\
\hline & & & & a NS & $a, b N S$ \\
\hline & \multirow{2}{*}{ Right } & \multirow{2}{*}{$474.50 \pm 18.43$} & \multirow{2}{*}{$508.00 \pm 10.44$} & $128.83 \pm 2.54$ & $502.50 \pm 27.19$ \\
\hline & & & & $a^{* * *}$ & a NS b*** \\
\hline
\end{tabular}

Values are expressed as ng /g of wet tissues mean \pm SEM. for six rats in each group. a Comparisons are made between Group I and Group III. b Comparisons are made between Group III and Group IV. III; NS: not significant; $\mathrm{P} \leq 0.001 * * * ; \mathrm{P} \leq 0.01 * * ; \mathrm{P} \leq 0.05 *$

(DA- Dopamine, DOPAC- Dihydroxyphenylacetic acid, HVA- Homovanillic acid) 
Graph 2. Level of dopamine and its metabolites in left striatum of 6-OHDA lesioned and HAE cells transplanted animals.

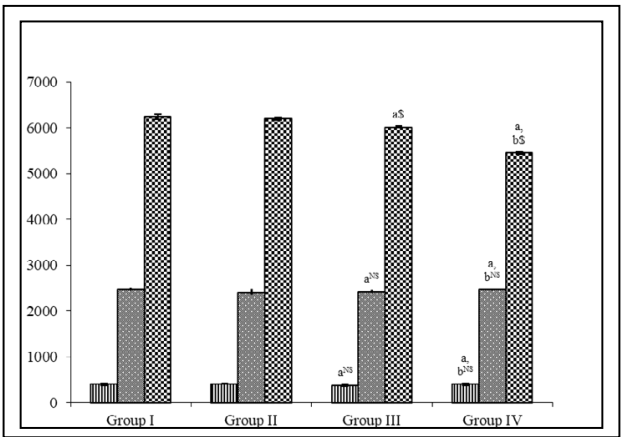

Graph 2 shows the level dopamine and its metabolites in the left striatum of lesioned and HAE cells transplanted animals. Each bar represents mean \pm standard error of six rats; Group I: Control; Group II: Sham control; Group II: 6-OHDA lesioned; Group IV: HAE cells transplant. a- comparison between Group I vs. III \& IV; b-

comparison between Group III vs. IV; NS- no significant; P $\leq 0.001-\$ ; \mathrm{P} \leq 0.01-\# ; \mathrm{P} \leq 0.05-@$.

Graph 3. Level of dopamine and its metabolites in right striatum of 6-OHDA lesioned and HAE cells transplanted animals.

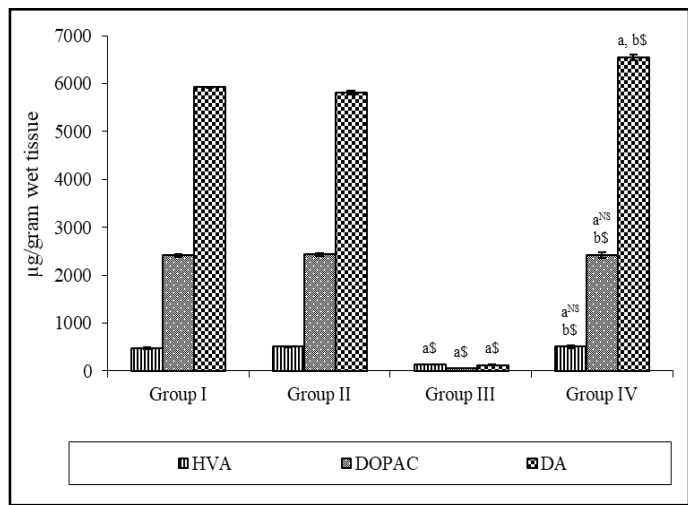

Graph 3 shows the level dopamine and its metabolites in the right striatum of lesioned and HAE cells transplanted animals. Each bar represents mean \pm standard error of six rats; Group I: Control; Group II: Sham control; Group II: 6-OHDA lesioned; Group IV: HA cells transplant. a- comparison between Group I vs. III \& IV; b-

comparison between Group III vs. IV; NS- not significant; P $\leq 0.001-\$ ;$ P $\leq 0.01-\# ; P \leq 0.05-@$.

Table 3. Level of dopamine and its metabolites in midbrain after 6-OHDA lesion and HAE cells transplantation.

\begin{tabular}{|c|c|c|c|c|c|}
\hline \multicolumn{2}{|c|}{ Parameters Side(s) } & Group I & Group II & Group III & Group IV \\
\hline \multirow{4}{*}{ DA } & \multirow{2}{*}{ Left } & \multirow{2}{*}{$587.83 \pm 13.53$} & \multirow{2}{*}{$584.50 \pm 19.75$} & $522.83 \pm 19.43$ & $451.33 \pm 19.21$ \\
\hline & & & & a NS & $\mathrm{a}^{* * *} \mathrm{~b}$ NS \\
\hline & \multirow{2}{*}{ Right } & \multirow{2}{*}{$535.16 \pm 18.82$} & \multirow{2}{*}{$546.50 \pm 19.48$} & $178.33 \pm 8.12$ & $462.00 \pm 25.95$ \\
\hline & & & & $a^{* * *}$ & $\mathrm{a}$ NS b*** \\
\hline \multirow{4}{*}{$\begin{array}{l}\text { DO- } \\
\text { PAC }\end{array}$} & \multirow{2}{*}{ Left } & \multirow{2}{*}{$274.16 \pm 11.93$} & \multirow{2}{*}{$262.16 \pm 11.24$} & $253.00 \pm 11.93$ & $233.00 \pm 11.71$ \\
\hline & & & & a NS & a NS b NS \\
\hline & \multirow{2}{*}{ Right } & \multirow{2}{*}{$319.83 \pm 15.14$} & \multirow{2}{*}{$278.33 \pm 14.98$} & $088.66 \pm 6.07$ & $311.16 \pm 21.91$ \\
\hline & & & & $a^{* * *}$ & a NS b*** \\
\hline \multirow{4}{*}{ HVA } & \multirow{2}{*}{ Left } & \multirow{2}{*}{$435.16 \pm 14.86$} & \multirow{2}{*}{$424.16 \pm 16.56$} & $372.50 \pm 14.78$ & $411.50 \pm 12.23$ \\
\hline & & & & $a^{*}$ & a NS b NS \\
\hline & \multirow{2}{*}{ Right } & \multirow{2}{*}{$494.16 \pm 15.76$} & \multirow{2}{*}{$447.83 \pm 15.90$} & $105.00 \pm 6.07$ & $395.50 \pm 23.09$ \\
\hline & & & & $a^{* * *}$ & $\mathrm{a}^{* *} \mathrm{~b}^{* * *}$ \\
\hline
\end{tabular}

Values are expressed as ng /g of wet tissues mean \pm SEM. for six rats in each group. : . a Comparisons are made between Group I and Group III. b Comparisons are made between Group III and Group IV. III; NS: not significant; $\mathrm{P} \leq 0.001 * * * ; \mathrm{P} \leq 0.01 * * ; \mathrm{P} \leq 0.05^{*}$

(DA- Dopamine, DOPAC- Dihydroxyphenylacetic acid, HVA- Homovanillic acid)

pus the DA $(22 \%)$ level was increased and not much alterations in its metabolites (DOPAC.7\%, HVA 2\%) when compared to the same side of the lesioned group (Table-5: Graph 8 and 9).

\section{Discussion}

\section{Apomorphine induced rotation}

The unilateral destruction of dopaminergic neurons causes chem- ical imbalance of the brain hemispheric content of the dopamine. Because of this chemical imbalance or asymmetry, the administration of certain dopamine agonists, such as apomorphine, causes stimulation of intact dopamine neurons in the unaffected brain hemisphere. This asymmetric stimulation is behaviorally manifested by locomotion in the direction of the unaffected hemisphere and animals run in circles. As reported by Bras and Glisk (1981); Jerussi and Glick (1976); Rioux et al. (1991);Ungerstedt and Arbuthnott (1970)[24, 25, 26, 27]. In the present work the 
Graph 4. Level of dopamine and its metabolites in left midbrain of 6-OHDA lesioned and HAE cells transplanted animals.

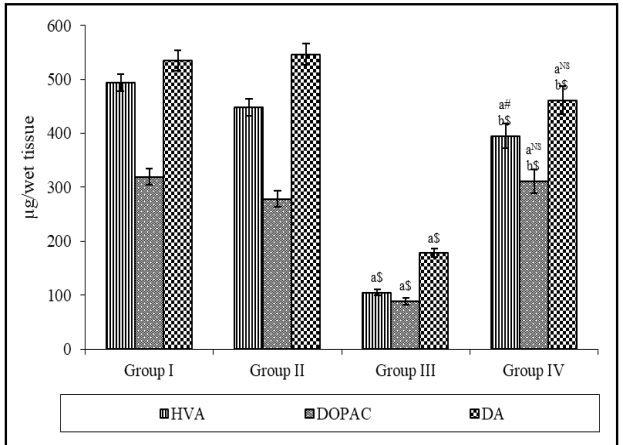

Graph 4 shows the level dopamine and its metabolites in the left midbrain of lesioned and HAE cells transplanted animals. Bars represent mean \pm standard error of six rats; Group I: Control; Group II: Sham control; Group II: 6-OHDA lesioned; Group IV: HAE cells transplant. a- comparison between Group I vs. III \& IV; b- comparison between Group III vs. IV; NS- not significant; P $\leq 0.001-\$ ; P \leq 0.01-\# ; P \leq 0.05-@$.

Graph 5. Level of dopamine and its metabolites in right midbrain of 6-OHDA lesioned and HAE cells transplanted animals.

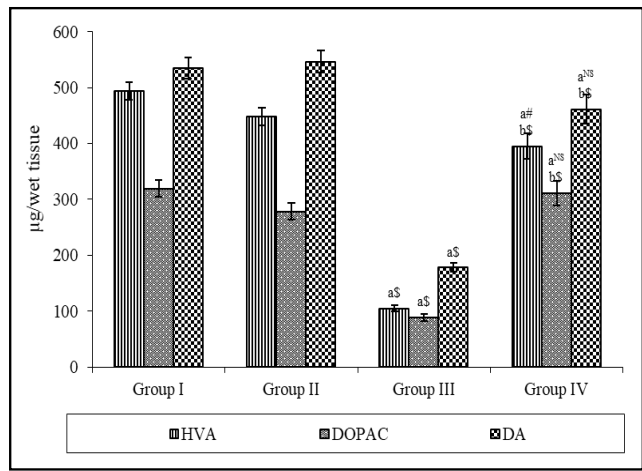

Graph 5 shows the level dopamine and its metabolites in the right midbrain of lesioned and HAE cells transplanted animals. Each bar represents mean \pm standard error of six rats; Group I: Control; Group II: Sham control; Group II: 6-OHDA lesioned; Group IV: HAE cells transplant. a- comparison between Group I vs. III \& IV; bcomparison between Group III vs. IV; NS- no significant; P $\leq 0.001-\$ ; \mathrm{P} \leq 0.01-\# ; \mathrm{P} \leq 0.05-@$.

Table 4. Level of dopamine and its metabolites in cerebral cortex after 6-OHDA lesion and HAE cells transplantation.

\begin{tabular}{|c|c|c|c|c|c|}
\hline \multicolumn{2}{|c|}{ Parameters Side(s) } & Group I & Group II & Group III & Group IV \\
\hline \multirow{4}{*}{ DA } & \multirow{2}{*}{ Left } & \multirow{2}{*}{$2428.16 \pm 20.87$} & \multirow{2}{*}{$2245.16 \pm 38.13$} & $1583.66 \pm 56.16$ & $2170.16 \pm 156.44$ \\
\hline & & & & $\mathrm{a}^{* * *}$ & a NS b*** \\
\hline & \multirow{2}{*}{ Right } & \multirow{2}{*}{$2454.50 \pm 25.26$} & \multirow{2}{*}{$2486.16 \pm 26.91$} & $77.83 \pm 2.68$ & $2392.50 \pm 34.14$ \\
\hline & & & & $\mathrm{a}^{* * *}$ & a NS b*** \\
\hline \multirow{4}{*}{ DOPAC } & \multirow[b]{2}{*}{ Left } & \multirow[b]{2}{*}{$605.00 \pm 21.35$} & \multirow[b]{2}{*}{$583.66 \pm 18.24$} & $276.16 \pm 15.41$ & $489.66 \pm 18.95$ \\
\hline & & & & $a^{* * *}$ & $\mathrm{a}^{* *} \mathrm{~b}^{* * *}$ \\
\hline & \multirow{2}{*}{ Right } & \multirow{2}{*}{$595.00 \pm 13.44$} & \multirow{2}{*}{$574.83 \pm 7.28$} & $123.66 \pm 5.27$ & $502.66 \pm 8.69$ \\
\hline & & & & $a^{* * *}$ & $\mathrm{a}^{* * *} \mathrm{~b}^{* * *}$ \\
\hline \multirow{4}{*}{ HVA } & \multirow{2}{*}{ Left } & \multirow{2}{*}{$570.00 \pm 15.45$} & \multirow{2}{*}{$539.33 \pm 12.67$} & $376.00 \pm 12.86$ & $511.50 \pm 24.66$ \\
\hline & & & & $\mathrm{a}^{* * *}$ & a NS b*** \\
\hline & \multirow{2}{*}{ Right } & \multirow{2}{*}{$537.66 \pm 15.86$} & \multirow{2}{*}{$522.66 \pm 19.18$} & $220.16 \pm 8.47$ & $494.16 \pm 11.85$ \\
\hline & & & & $a^{* * *}$ & a NS b*** \\
\hline
\end{tabular}

Values are expressed as ng /g of wet tissues mean \pm SEM. for six rats in each group. : . a Comparisons are made between Group I and Group III. b Comparisons are made between Group III and Group IV. III; NS: not significant; $\mathrm{P} \leq 0.001 * * * ; \mathrm{P} \leq 0.01 * * ; \mathrm{P} \leq 0.05^{*}$

(DA- Dopamine, DOPAC- Dihydroxyphenylacetic acid, HVA- Homovanillic acid)

animals shows pronounced APO Hclinduced contralateral rotation for seven days after the lesion and it was persisted till thirty to forty days after the unilateral lesion with 6-OHDA in the striatum. The HAE cells transplanted animals showed the reduced apomorphine induced contralateral rotation behaviour. There may be two possibilities for reduced apomorphine induced rotation in the HAE cell transplanted animals; the first one is the reorganization of the association between striatal D1 and D2 subfamily receptors. Second, the reduced turning may represent an effect of HAE cells graft to promote the recovery of behavioural functions in the denervated striatum.

\section{Neurotransmitters}

There are many evidences showing that DA neurons death in PD model in involves the accumulation of free radicals in the SN[28]. 
Graph 6. Level of dopamine and its metabolites in left cerebral cortex of 6-OHDA lesioned and HAE cells transplanted animals.

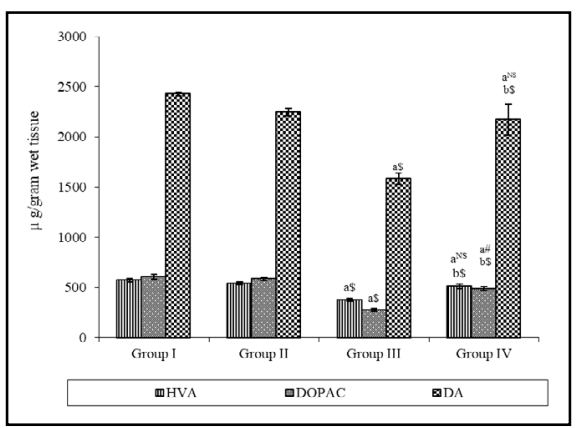

Graph 6 shows the level dopamine and its metabolites in the left cerebral cortex of lesioned and HAE cells transplanted animals. Bars represent mean \pm standard error of six rats; Group I: Control; Group II: Sham control; Group II: 6-OHDA lesioned; Group IV: HAE cells transplant. a- comparison between Group I vs. III \& IV; bcomparison between Group III

vs. IV; NS- not significant; $\mathrm{P} \leq 0.001-\$ ; \mathrm{P} \leq 0.01$-\#; $\mathrm{P} \leq 0.05-@$.

Graph 7. Level of dopamine and its metabolites in right cerebral cortex of 6-OHDA lesioned and HAE cells transplanted animals.

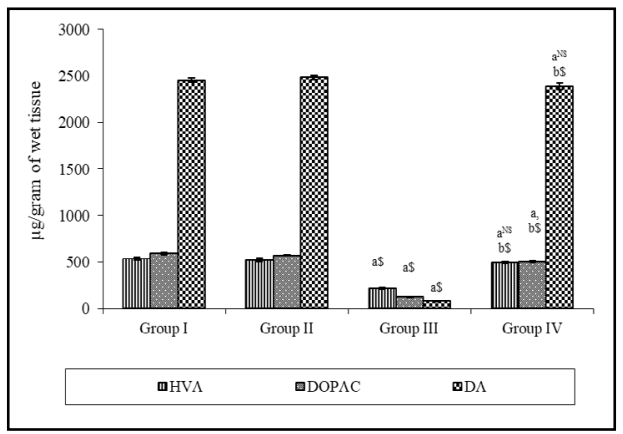

Graph 7 shows the level dopamine and its metabolites in the right cerebral cortex of lesioned and HAE cells transplanted animals; each bar represents mean \pm standard error of six rats; Group I: Control; Group II: Sham control; Group II: 6-OHDA lesioned; Group IV: HAE cells transplant. a- comparison between Group I vs. III \& $\mathrm{IV}$; b- comparison between

Group III vs. IV; NS- not significant; $\mathrm{P} \leq 0.001$-\$; P $\leq 0.01$-\#; $\mathrm{P} \leq 0.05-@$.

Table 5. Level of dopamine and its metabolites in Hippocampus after 6-OHDA lesion and HAE cells transplantation.

\begin{tabular}{|c|c|c|c|c|c|}
\hline \multicolumn{2}{|c|}{ Parameters Sides } & Group I & Group II & Group III & Group IV \\
\hline \multirow{4}{*}{$\mathrm{DA}$} & \multirow{2}{*}{ Left } & \multirow{2}{*}{$1177.33 \pm 32.65$} & \multirow{2}{*}{$1147.16 \pm 18.50$} & $1012.33 \pm 22.70$ & $1238.50 \pm 33.84$ \\
\hline & & & & $a^{* *}$ & a NS b*** \\
\hline & \multirow{2}{*}{ Right } & \multirow{2}{*}{$1173.50 \pm 28.39$} & \multirow{2}{*}{$1224.83 \pm 29.16$} & $858.66 \pm 15.51$ & $1168.16 \pm 26.06$ \\
\hline & & & & $a^{* * *}$ & a NS b*** \\
\hline \multirow{4}{*}{ DOPAC } & \multirow{2}{*}{ Left } & \multirow{2}{*}{$260.33 \pm 9.48$} & \multirow{2}{*}{$282.33 \pm 6.55$} & $281.33 \pm 7.22$ & $283.83 \pm 6.97$ \\
\hline & & & & a NS & a NS b NS \\
\hline & \multirow{2}{*}{ Right } & \multirow{2}{*}{$301.66 \pm 11.34$} & \multirow{2}{*}{$288.50 \pm 9.59$} & $64.66 \pm 52.21$ & $285.50 \pm 9.76$ \\
\hline & & & & $a^{* * *}$ & a NS b*** \\
\hline \multirow{4}{*}{ HVA } & Left & $9201.16 \pm 59.65$ & $9184.00 \pm 55.43$ & $\begin{array}{c}8700.00 \pm \\
108.80\end{array}$ & $8889.66 \pm 164.49$ \\
\hline & \multirow{3}{*}{ Right } & \multirow{3}{*}{$8936.16 \pm 114.08$} & \multirow{3}{*}{$9070.33 \pm 103.79$} & $4531.83 \pm 38.81$ & $8699.16 \pm 78.00$ \\
\hline & & & & $a^{* * *}$ & a NS b*** \\
\hline & & & & & \\
\hline
\end{tabular}

Values are expressed as ng / $\mathrm{g}$ of wet tissues mean \pm SEM. for six rats in each group. : a Comparisons are made between Group I and Group III. b Comparisons are made between Group III and Group IV. III; NS: not significant; P $\leq 0.001 * * * ; P \leq 0.01 * * ;$ P $\leq 0.05^{*}$ (DA- Dopamine, DOPAC- Dihydroxyphenylacetic acid, HVA- Homovanillic acid)

It is known that the most prominent biochemical changes in the 6-OHDA lesioned striatum are reductions in DA and its metabolite levels. This effect causes characteristic motor dysfunctions revealed by the treatment with dopamine receptor agonists, resulting in rotation in a direction contralateral to that of the lesion.

In this study there was a considerable reduction of dopamine and its metabolites in ipsilateral to the 6-OHDA infusion than the contralateral side of different brain regions, such as striatum, midbrain, cerebral cortex andhippocampus. In striatum, level of DA, DOPAC and HVA were significantly reduced on the lesioned side than the contralateral side and non lesioned animals. Midbrain also showed noticeable change in DA and its metabolites when compared to the contralateral side of the lesioned and non 
Graph 8. Level of dopamine and its metabolites in left hippocampus of 6-OHDA lesioned and HAE cells transplanted animals.

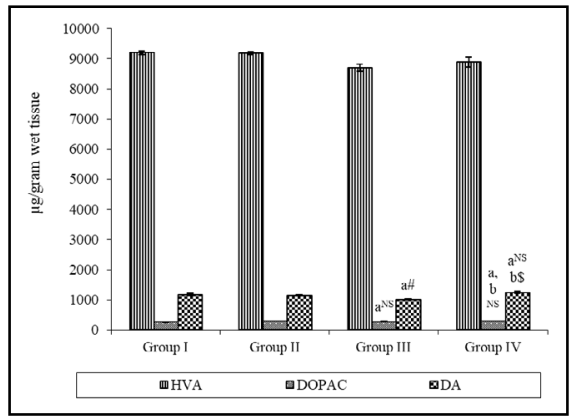

Graph 8 shows the level dopamine and its metabolites in the left hippocampus cortex of lesioned and HAE cells transplanted animals; each bar represents mean \pm standard error of six rats; Group I: Control; Group II: Sham control; Group II: 6-OHDA lesioned; Group IV: HAE cells transplant. a- comparison between Group I vs. III \& IV; b- comparison between

Group III vs. IV; NS- not significant; $\mathrm{P} \leq 0.001$-\$; $\mathrm{P} \leq 0.01$-\#; $\mathrm{P} \leq 0.05-@$.

Group 9. Level of dopamine and its metabolites in right hippocampus of 6-OHDA lesioned and HAE cells transplanted animals.

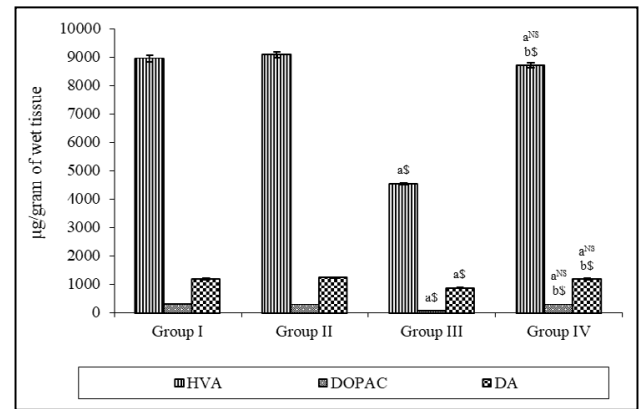

Graph 9 defines the level dopamine and its metabolites in the right hippocampus cortex of lesioned and HAE cells transplanted animals; each bar represents mean \pm standard error of six rats; Group I: Control; Group II: Sham control; Group II: 6-OHDA lesioned; Group IV: HAE cells transplant. a- comparison between Group I vs. III \& IV; b- comparison between

Group III vs. IV; NS- not significant; P $\leq 0.001-\$$; $\leq 0.01$-\#; P $\leq 0.05-@$.

lesioned animals. In hippocampus the significant reduction could be identified in DOPAC and HVA in ipsilateral to the lesion over the contralateral and control animals, whereas the level of DA significantly reduced in both side of the hippocampus. In cerebral cortex the level of DA and its metabolites were significantly reduced in lesioned animals than the control animal's cortex. This effect would involve a dopamine receptor super-sensitivity caused by the loss of DA terminals and resulting in a significant reduction of DA levels in the 6-OHDA-lesioned striatum. These findings were consistent with other studies describing biochemical changes in the 6-OHDA lesioned striatum [29, 30].

Researcher reported that the HAE cells have multipotent differentiation ability and may serve as seed cells for the cell transplantation. They can differentiate into all three germ layer derived cells, such as neurocytes, hepatocytes, and islet cells [31, 32, 33, 34]. They have low immunogenicity and may exert anti-inflammatory effect. The HAE cells derived from the discarded amnion after parturition is expected to serve as an attractive seed cells in the regenerative medicine [35]. So the usage of HAE cells in neural repair does not require any ethical clearance as well it curtail the use of human embryos as in the case of embryonic stem cells $[36,37]$.

The HAE cells transplanted animals showed significant recovery on the level of neurotransmitter with the correlation of motor behaviour. Increase of DA and its metabolites in brain region after the HAE cells graft may therefore probably be dependent upon the diffusion of certain neurotrophic factors in the region of graft in the striatum and also due to intimacy of contact between graft and host striatum. Therefore, this may provide a simple model that allows, alleviating functional and biochemical deficits after creating the experimental neurodegenerative disease model in animals. The HAE cells are ideal donors to treat the human, who are suffering from the certain neurodegenerative disease. However the actual synaptic contacts between HAE cells graft and host were not observed. Survival and interaction of HAE cells in the host brain have been illustrated in the histological observation and it was published elsewhere [38].

\section{Summary and Conclusion}

The present work shows that the pronounced DA depletion with 6-OHDA lesion and recovered during long term survival of the human amniotic epithelia cells in the DA depleted striatum and its connections of associated regions in rodent brain. We conclude that the HAE cells may be used as a donor tissue to treat various neuro-degenerative ailments in the human which are not curable with the traditional drugs and other methods of treatment.

\section{Acknowledgements}

This work was supported by the Department of anatomy, University of Madras in the form of Tamil Nadu Junior Research Fellowship (TNJRF). The authors thank Dr. Elumalai Prithviraj for his assistance in preparing the statistical analysis of the pre- 
sent work.

\section{References}

[1]. Ren JP, Zhao YW, Sun XJ. Toxic influence of chronic oral administration of paraquat on nigrostriatal dopaminergic neurons in C57BL/6 mice. Chin Med J (Engl). 2009 Oct 5;122(19):2366-71.Pubmed PMID: 20079141.

[2]. Peran P, Cherubini A, Assogna F, Piras F, Quattrocchi C, Peppe A, et al. Magnetic resonance imaging markers of Parkinson's disease nigrostriatal signature. Brain. 2010 Nov;133(11):3423-33.Pubmed PMID: 20736190.

[3]. Hollerman JR, Grace AA. The effects of dopamine-depleting brain lesions on the electrophysiological activity of rat substantia nigra dopamine neurons. Brain Res. 1990 Nov 19;533(2):203-12.Pubmed PMID: 2126975.

[4]. Gonon FG, Buda MJ. Regulation of dopamine release by impulse flow and by autoreceptors as studied by in vivo voltammetry in the rat striatum. Neuroscience. 1985 Mar;14(3):765-74.Pubmed PMID: 2986044

[5]. Miller GW, Gainetdinov RR, Levey AI, Caron MG. Dopamine transporters and neuronal injury. Trends Pharmacol. Sci. 1999 Oct 1;20(10):424-9.

[6]. Counihan TJ, Penney JB Jr. Regional dopamine transporter gene expression in the substantia nigra from control and Parkinson's disease brains. J Neurol Neurosurg Psychiatry. 1998 Aug;65(2):164-9.Pubmed PMID: 9703165.

[7]. Kirik D, Rosenblad C, Björklund A. Characterization of behavioral and neurodegenerative changes following partial lesions of the nigrostriatal dopamine system induced by intrastriatal 6-hydroxydopamine in the rat. Exp Neurol. 1998 Aug;152(2):259-77.Pubmed PMID: 9710526.

[8]. Blum D, Torch S, Lambeng N, Nissou M, Benabid AL, Sadoul R, et al. Molecular pathways involved in the neurotoxicity of 6-OHDA, dopamine and MPTP: contribution to the apoptotic theory in Parkinson's disease. Prog Neurobiol. 2001 Oct;65(2):135-72.Pubmed PMID: 11403877.

[9]. Betarbet R, Sherer TB, Greenamyre JT. Animal models of Parkinson's disease. Bioessays. 2002 Apr;24(4):308-18.

[10]. Deumens R, Blokland A, Prickaerts J. Modeling Parkinson's disease in rats: an evaluation of 6-OHDA lesions of the nigrostriatal pathway. ExpNeurol. 2002 Jun 1;175(2):303-17.

[11]. Ilancheran S, Moodley Y, Manuelpillai U. Human fetal membranes: a source of stem cells for tissue regeneration and repair?. Placenta. 2009 Jan $1 ; 30(1): 2-10$.

[12]. Manuelpillai U, Moodley Y, Borlongan CV, Parolini O. Amniotic membrane and amniotic cells: potential therapeutic tools to combat tissue inflammation and fibrosis? Placenta. 2011 Oct;32 Suppl 4:S320-5.Pubmed PMID: 21570115.

[13]. Parolini O, Alviano F, Bagnara GP, Bilic G, Bühring HJ, Evangelista M, et al. Concise review: isolation and characterization of cells from human term placenta: outcome of the first international Workshop on Placenta Derived Stem Cells. Stem Cells. 2008 Feb;26(2):300-11.Pubmed PMID: 17975221.

[14]. Wolbank S, Peterbauer A, Fahrner M, Hennerbichler S, van Griensven M, Stadler G, et al. Dose-dependent immunomodulatory effect of human stem cells from amniotic membrane: a comparison with human mesenchymal stem cells from adipose tissue. Tissue Eng. 2007 Jun;13(6):1173-83.Pubmed PMID: 17518752 .

[15]. Zhang R, Cai Y, Xiao R, Zhong H, Li X, Guo L, et al. Human amniotic epithelial cell transplantation promotes neurogenesis and ameliorates social deficits in BTBR mice. Stem Cell Res Ther. 2019 May 31;10(1):153.Pubmed PMID: 31151403.

[16]. Herman JP, Watson SJ. The rat brain in stereotaxic coordinates (2nd edn): by George Paxinos and Charles Watson, Academic Press, 1986.

[17]. Bartholini G, Richards JG, Pletscher A. Dissociation between biochemical and ultrastructural effects of 6-hydroxydopamine in rat brain. Experientia. 1970 Feb 1;26(2):142-4.

[18]. Sakuragawa N, Thangavel R, Mizuguchi M, Hirasawa M, Kamo I. Expression of markers for both neuronal and glial cells in human amniotic epithelial cells. Neurosci Lett. 1996 May 3;209(1):9-12.Pubmed PMID: 8734897.

[19]. Sakuragawa N, Misawa H, Ohsugi K, Kakishita K, Ishii T, Thangavel R, et al. Evidence for active acetylcholine metabolism in human amniotic epithelial cells: applicable to intracerebral allografting for neurologic disease. Neurosci Lett. 1997 Aug 22;232(1):53-6. PubmedPMID: 9292890

[20]. Ungerstedt U. Stereotaxic mapping of the monoamine pathways in the rat brain. Acta Physiol Scand Suppl. 1971;367:1-48.Pubmed PMID: 4109331.
[21]. Olsson M, Nikkhah G, Bentlage C, Bjorklund A. Forelimb akinesia in the rat Parkinson model: differential effects of dopamine agonists and nigral transplants as assessed by a new stepping test. . J Neurosci. 1995 May $1 ; 15(5): 3863-75$.

[22]. Glowinski J, Iversen LL. Regional studies of catecholamines in the rat brain. I. The disposition of $[3 \mathrm{H}]$ norepinephrine, $[3 \mathrm{H}]$ dopamine and $[3 \mathrm{H}]$ dopa in various regions of the brain. J Neurochem. 1966 Aug;13(8):655-69.Pubmed PMID: 5950056.

[23]. Khaldy H, Escames G, León J, Vives F, Luna JD, Acuña-Castroviejo D. Comparative effects of melatonin, L-deprenyl, Trolox and ascorbate in the suppression of hydroxyl radical formation during dopamine autoxidation in vitro. J Pineal Res. 2000 Sep;24:215-218.Pubmed PMID: 10981823.

[24]. Brass CA, Glick SD. Sex differences in drug-induced rotation in two strains of rats. Brain Res. 1981 Oct 26;223(1):229-34.Pubmed PMID: 7284807.

[25]. Jerussi TP, Glick SD. Drug-induced rotation in rats without lesions: behavioral and neurochemical indices of a normal asymmetry in nigro-striatal function. Psychopharmacology (Berl). 1976 Jun 23;47(3):249-60.Pubmed PMID: 823560

[26]. Rioux L, Gaudin DP, Bui LK, Grégoire L, DiPaolo T, Bédard PJ. Correlation of functional recovery after a 6-hydroxydopamine lesion with survival of grafted fetal neurons and release of dopamine in the striatum of the rat. Neuroscience. 1991;40(1):123-31.Pubmed PMID: 1904997.

[27]. Ungerstedt U, Arbuthnott GW. Quantitative recording of rotational behavior in rats after 6-hydroxy-dopamine lesions of the nigrostriatal dopamine system. Brain Res. 1970 Dec 18;24(3):485-93.Pubmed PMID: 5494536.

[28]. Latchoumycandane C, Anantharam V, Jin H, Kanthasamy A, Kanthasamy A. Dopaminergic neurotoxicant 6-OHDA induces oxidative damage through proteolytic activation of PKC $\delta$ in cell culture and animal models of Parkinson's disease. Toxicol Appl Pharmacol. 2011 Nov 1;256(3):314-23. Pubmed PMID: 21846476.

[29]. Ichitani Y, Okamura H, Nakahara D, Nagatsu I, Ibata Y. Biochemical and immunocytochemical changes induced by intrastriatal 6-hydroxydopamine injection in the rat nigrostriatal dopamine neuron system: evidence for cell death in the substantia nigra. Exp Neurol. 1994 Dec 1;130(2):269-78.

[30]. Karstaedt PJ, Kerasidis H, Pincus JH, Meloni R, Graham J, Gale K. Unilateral destruction of dopamine pathways increases ipsilateral striatal serotonin turnover in rats. Exp Neurol. 1994 Mar;126(1):25-30.Pubmed PMID: 7512513.

[31]. Kakishita K, Elwan MA, Nakao N, Itakura T, Sakuragawa N. Human amniotic epithelial cells produce dopamine and survive after implantation into the striatum of a rat model of Parkinson's disease: a potential source of donor for transplantation therapy. Exp Neurol. 2000 Sep;165(1):27-34. Pubmed PMID: 10964482

[32]. Scaggiante B, Pineschi A, Sustersich M, Andolina M, Agosti E, Romeo D. Successful therapy of Niemann-Pick disease by implantation of human amniotic membrane. Transplantation. 1987 Jul;44(1):59-61.Pubmed PMID: 3037739.

[33]. Takashima S, Ise H, Zhao P, Akaike T, Nikaido T. Human amniotic epithelial cells possess hepatocyte-like characteristics and functions. Cell Struct Funct. 2004 Jun;29(3):73-84.Pubmed PMID: 15528839.

[34]. Wei JP, Zhang TS, Kawa S, Aizawa T, Ota M, Akaike T, et al. Human amnion-isolated cells normalize blood glucose in streptozotocin-induced diabetic mice. Cell Transplant. 2003;12(5):545-52.Pubmed PMID: 12953929.

[35]. Toda A, Okabe M, Yoshida T, Nikaido T. The potential of amniotic membrane/amnion-derived cells for regeneration of various tissues. J PharmacolSci. 2007;105(3):215-28.

[36]. Rebmann V, Pfeiffer K, Pässler M, Ferrone S, Maier S, Weiss E, et al. Detection of soluble HLA-G molecules in plasma and amniotic fluid. Tissue Antigens. 1999 Jan;53(1):14-22.Pubmed PMID: 10082427.

[37]. Rooney IA, Morgan BP. Characterization of the membrane attack complex inhibitory protein CD59 antigen on human amniotic cells and in amniotic fluid. Immunology. 1992 Aug;76(4):541-547.

[38]. Ravisankar P, Omprakash KV, Muthusamy R, Ramesh kumar R, Ravindran R, Sheeladevi R. Behavioral and Histological Observations after the Human Amniotic Epithelial Cells Transplantation in the 6-Hydroxydopamine induced parkinsonism disse model in Wistar albino rats. Int. J of Recent Trends in Science and Tech.2014; 10 (2):378-385. 